Johnson \& Wales University ScholarsArchive@JWU

Economics Department Faculty Publications \&

Research

College of Arts \& Sciences

2011

\title{
A Theory of Entangled Political Economy, with Application to TARP and NRA
}

Adam Smith

Johnson \& Wales University - Charlotte, adam.smith@jwu.edu

Follow this and additional works at: https://scholarsarchive.jwu.edu/econ_fac

Part of the Other Economics Commons

\section{Repository Citation}

Smith, Adam, "A Theory of Entangled Political Economy, with Application to TARP and NRA" (2011). Economics Department Faculty

Publications \& Research. 3.

https://scholarsarchive.jwu.edu/econ_fac/3

This Article is brought to you for free and open access by the College of Arts \& Sciences at ScholarsArchive@JWU. It has been accepted for inclusion in Economics Department Faculty Publications \& Research by an authorized administrator of ScholarsArchive@JWU. For more information, please contact jcastel@jwu.edu. 


\title{
A Theory of Entangled Political Economy, with Application to TARP and NRA
}

\author{
Adam Smith*, Richard E. Wagner*, and Bruce Yandle** \\ *George Mason University \\ **Clemson University and George Mason University's Mercatus Center
}

\begin{abstract}
The recent financial crisis has provoked a raft of contending claims as to whether the cause of the crisis is better attributed to market failure or political failure. Such claims are predicated on a presumption that markets and polities are meaningfully separate entities. To the contrary, we argue that contemporary arrangements create an entangled political economy that renders theorizing based on separation often misleading. Within this alternative framework of entangled political economy, we illuminate both the recent Troubled Assets Relief Program (TARP) and the New Deal's National Recovery Administration (NRA).
\end{abstract}

Keywords: bailout, political economy, credit markets, economic calculation, constitutional economics

JEL Codes: E6, D7, H1 


\section{Introduction}

The recent disturbances within financial markets, along with the accompanying recession, have caused reverberations within academic circles as well as throughout the economies of the world. Within academic circles, a clear polarity has appeared concerning the locus of blame. On one side of that polarity stand claims that the crisis is an instance of market failure, which demonstrates the need for stronger regulatory control over markets, as illustrated by Cohan (2009), Posner (2009), and Shiller (2008). On the other side stand claims that the crisis is a manifestation of excessive regulation, the remedy for which is less regulation, as illustrated by Sowell (2009), Taylor (2009), White (2008), and Woods (2009).

We do not seek here to adjudicate these contending claims, at least not in any direct fashion, because our object of analytical interest is the theory of political economy and not macro-level instability per se. ${ }^{1}$ Our concern here is with the conceptual treatment of systems of political economy, using some macro-level material associated with economic disturbance to provide substantive content. "Political economy" is a compound term formed from the elements polity and economy, each of which in turn can be conceptualized as pure forms. The question at hand is how to combine those pure forms to arrive at political economy. The common way is to do so through sequential addition, as conveyed crisply in Persson and Tabellini (2000) and Besley (2006). Within this framework, market equilibrium is established theoretically prior to

\footnotetext{
${ }^{1}$ We would demur, however, from the numerous remarks that have claimed that the recent events have shown the inadequacy of all macro-level theories. They have shown the inadequacy of theories of the income-expenditure variety where present actions produce current results. But Austrian-style theories, where credit expansion today can cause a boom tomorrow while also causing a bust the day after tomorrow have been generally on the mark. While much work remains to be done in developing this line of explanation, as Wagner (1999) explores, it does explain how credit expansion can produce a sequence of boom-and-bust.
} 
and independently of political action, with subsequent political intervention establishing an alternative equilibrium. This sequential and separable framework is, of course, used to divergent effect: where some claim that political intervention promotes Pareto efficiency or something close to it, others claim that it generates significant losses associated with rent seeking (Tullock 1967) and rent extraction (McChesney 1997).

The separated framework leads naturally to efforts to locate the source of disturbance as originating in either polity or economy. For instance, Congleton (2009) attributes the recent disturbance largely to market processes; alternatively, Rowley and Smith (2009) conclude that causation resides with political action. In contrast, our framework of entangled and simultaneous political economy, as sketched in Wagner (2006, 2007), highlights a third possible option: the recent disturbance is a systemic feature of a constitutional system of entangled political economy. ${ }^{2}$ We start by setting forth our framework of entangled political economy and compare it with separated political economy. After doing this we examine two historical episodes to illustrate the explanatory ability of the entangled framework. The first of those episodes is the recent development of the Troubled Assets Relief Program (TARP); the second is the National Recovery Administration (NRA) of the New Deal.

\section{Two conceptualizations of political economy}

Any analytical framework unavoidably highlights some phenomena while ignoring other phenomena. Within the framework of separated political economy, the final societal equilibrium is generated by sequential addition over two distinct institutional

\footnotetext{
${ }^{2}$ In this vein, we would note that Oliver Kessler (2009) likewise advances a systemic line of explanation, though from an analytic orientation grounded in economic sociology.
} 
frameworks: a market framework governed by private property and freedom of contract and a constitutional framework that governs political transactions. Actions taken in the political arena thus modify the equilibrium established within the market arena. A further significant feature of this framework is that polity and economy are each conceptualized as single, point-mass entities that act upon one another.

Figure 1 illustrates this analytical framework. The polity is denoted by the octagon, the economy by the square. As shown there, the polity acts as a single massed entity on the economy which responds as a single massed entity by shifting from $E$ to $E^{*}$ due to political action on the economy, much as one billiard ball would act upon another. Separated political economy theorizes by a process of layered addition. The theory proceeds smoothly and sequentially, with economic entities acting first and political entities second. The outcome of this model of political economy corresponds to what we observe after the second move.

The alternative framework of entangled political economy differs in several significant respects from that of separated political economy. For one thing, polity and economy are not conceptualized through reduction to point-mass status. There is, after all, nothing about billiard balls that would allow entanglement. For entanglement to be possible, the entities must be conceptualized as networks of relationships where individual nodes craft particular connections with other nodes, and with those connections running through both are arenas of action. Furthermore, market and political actions are undertaken simultaneously, and within an institutional framework that is open to all actors in both arenas. Polity and economy are both arenas of activity 
that contain numerous interacting enterprises that are connected in network fashion whose systemic properties depend on the structure of the network.

Figure 2 illustrates in simplified fashion a framework of entangled political economy. The figure is simplified because the individual entities in the economy are portrayed as stand-alone entities and not as existing within a network, so as to reduce the clutter of connections among economic entities that would otherwise appear. The main feature of interest in Figure 2 is that neither polity nor market is reducible to pointmass status. Individual political enterprises differ in the economic entities on which they act, and with different locations of political action generating different economic consequences due to different patterns of network connection among economic entities (which have been suppressed in Figure 2).

While competition among and across commercial and political entities is a key characteristic of the entangled political economy, specialized and divided knowledge is a central feature of this process (Hayek 1945). Smith and Yandle (2009) explain how this divided knowledge generates global patterns that never were the direct object of any participant's choice, but rather were emergent properties of systemic interaction. As agreements are reached, statutes modified, and regulations written, a package of outcomes emerges that no one has chosen, not even senior members of the legislative and executive branches of government. Each participant pursues opportunities for gain within a networked system of complex interaction where the overall outcome is not a product of intentional choice.

This formulation of entangled political economy is not new, though the reductionist-driven imperative of tractable modeling has relegated it to the background 
of theoretical inquiry. For instance, Jonathan Hughes (1977) presents a wide-ranging account of entangled political economy going back to colonial times in America, where polity and economy evolved simultaneously through entangled interaction (Yandle, 1984). On a conceptual level, Jane Jacobs (1992) describes societal processes that evolve through interaction between institutional carriers of two distinct moralities, which she describes as the commercial and the guardian moral syndromes. A central feature of her analysis is the treatment of some of the debilitating qualities of certain patterns of entanglement, and which she describes as "monstrous moral hybrids," and which to some extent is reflected in Jonah Goldberg's (2008) treatment of Liberal Fascism and also in Bruce Yandle's (1983) treatment of Baptists and bootleggers. Indeed, entanglement-driven regulation that delivers special benefits for one part or sector of the political economy while imposing costs another is recognized as far back as Magna Charta (Yandle 1984) and as recently as the 2010 debate over cap-and-trade carbon emission regulation (Yandle, 2010b). In those two cases and with entanglement generally, political connections and social structure, long developed between interest groups and political power brokers, become energized and highly visible when some political or economic shock sets the stage for action. At other times, lobbyists and politicians, whose political survival depends on serving and balancing the demands of multiple competing interests, happily maintain the connecting networks.

Our analytical framework has both similarities to and differences with Sanford Ikeda's (1997) and Steve Littlechild's (1997) treatments of the dynamics of interventionism. The similarities reside in a common concern with the systemic properties of interaction between economic and political entities, and with entanglement 
in both cases being a continuing process. The differences reside in our use of a network-based formulation in contrast to the field-based formulation of Ikeda and Littlechild. As Jason Potts (2000) explains, network-based formulations are more suitable for exploring patterns of continual evolution where the emphasis is placed on particular patterns of entanglement and not on the general presence of entanglement. Thus our formulation extends the earlier formulations by supplying some gain-seeking logic by which particular patterns of entanglement are generated.

With regard to institutional arrangements, Elinor Ostrom (1986) reminds us that it is not sufficient to describe the political process as exogenous if we hope to understand outcomes as they emerge in naturally occurring environments. It is necessary to go further by undertaking an examination of the actual organization of decision-making in particular institutional contexts, because different particular contexts can yield different patterns of outcome, as Ostrom (2005) explains. Only in this way will we be able to understand why certain outcomes emerge rather than others. Ostrom's theme informs our own effort to work with a theory of entangled political economy because we think that this institutional framework more accurately reflects the institutional framework from which the present situation has emerged.

\section{Entangled political economy and the triadic architecture of exchange}

Within the pure theory of a market economy, a transaction entails a dyadic relationship between buyer and seller, and with the terms of trade reflecting agreement between them. Those transactions can be aggregated and then reasonably reduced to 
a representative transaction without losing economically significant information. A credit transaction within the pure theory of a market economy would involve a relationship between borrower and lender and no one else. In choosing among borrowers, lenders would base decisions on their appraisal of the anticipated commercial value of proposed transactions, as this value is governed within the framework of private property and freedom of contract. A borrower whose offer is rejected by a lender can try other lenders, but transactions between borrowers and lenders are dyadic relationships in any case.

Political action can be introduced into such transactions in two distinct ways, as Walter Eucken (1952) explains in his distinction between political actions that are market-conformable and those that are not. While it may be doubtful that market conformability is a dichotomous state as against denoting some continuum, the distinction between conformable and non-conformable actions still has traction in distinguishing separated from entangled political economy. ${ }^{3}$ Should political actions conform to the operating features of the market economy, the outcome could be described as an instance of separated political economy. Political action would affect all credit transactions in non-discriminatory fashion, in which case it would still be reasonable to reduce the aggregate of credit transactions to a representative transaction. Figure 1 denotes a situation where political actions are market conformable in that they act upon the market as an entity and are neutral toward the pattern of activities within the market. Within a framework of separated political economy, political

\footnotetext{
${ }^{3}$ In similar fashion, neutral taxation surely depicts a continuum and not a dichotomy. The alleged neutrality of a head tax assumes wrongly that heads can be counted accurately independently of the size of the tax. A head tax may be comparatively neutral among contemporary tax instruments, but the enumerated size of a population would surely vary inversely with the size of the tax.
} 
action tweaks market outcomes without modifying the modus operandi of the market process. Market transactions would retain their dyadic quality, with a polity entity offering bounties to market-based entities but without getting involved in the operation of those entities.

In contrast, political actions that are non-conformable with market processes generate an entangled political economy, one illustration of which is presented in Figure 2. Within this alternative framework, transactions are triadic as political entities participate in market transactions. It is no longer reasonable to reduce some market aggregate to a representative transaction because the behavior of that aggregate will vary with the particular network structure from which the aggregate emerges; such networks are scale-free, so there is no scale by which an aggregate can be reduced to a representative transaction (Barabási 2002). Transactions occur between particular entities within the market and the polity and not between market and polity as pointmass entities. The triadic quality of transactions, moreover, shifts the character of commercial calculation. In dyadic exchanges between market entities, both parties share a common focal point due to their residual claimant positions. This focal point, for instance, explains why the preponderance of commercial disputes is settled without trial. With the triadic transactions of entangled political economy, the salience of the common focal point weakens due to the absence of residual claimancy within political entities.

With dyadic transactions, a lender calculates by ordering borrowers in terms of potential profitability when that profitability depends only on the forecasted repayment activity of the borrower. With triadic transactions, this simple calculus gives way to a 
more complex calculus that is not readily reducible to a scalar magnitude, due to the absence of residual claimancy. Transactions cannot be ordered by their reduction to scalar magnitudes because they retain vector qualities. For instance, transactions might be subject to side constraints that reflect perceived regulatory preferences regarding the distribution of loans by age, race, gender, or location, to select four categories commonly in play. Regulatory monitoring, however, is never subject to open calculation but rather invariably involves significant measures of arbitrariness that impedes economic calculation as compared with dyadic exchange.

Profit takes a different form when pursued by political entities than when pursued by market entities. There is, however, no unique form that pursuit takes, which injects further complication into economic calculation. Figure 3 illustrates this point. Political entities are organized within a framework of inalienable ownership, in contrast to market entities. Hence, profit cannot be appropriated directly through political entities. Yet profit is always present because it merely signifies mutual gains for the parties to a transaction. Hence, a nonprofit status does not eliminate the search for profit but only changes the paths taken by that search. Panel A illustrates an exchange between two market entities denoted by the squares, and with each party expecting to profit from the trade as denoted by the arrows running to the small circles outside the squares. Panel B illustrates a similar exchange when one party is a political entity. While both sides expect to profit, political profit cannot be appropriated directly, and yet the anticipation of profit will be there or else the enterprise would not have been sponsored. The small triangle located between and to the right of the political and market entities indicates that profit is channeled in some indirect fashion, as illustrated by the cloud into which 
that profit flows. The image of the cloud is meant to cover the variety of particular ways that such profit might be appropriated: it could be appropriated though higher prices paid to particular input suppliers; it could also be appropriated by offering lower prices to favored buyers. Regardless of the form of appropriation, entangled political economy will feature the appropriation of profits through triadic exchange relationships.

Entangled political economy theorizes in terms of universal profit-seeking pursued simultaneously in both arenas. While political entities cannot appropriate profit directly from their activities, successful political action will nonetheless create profits to be appropriated, for profit is just another word for gain. What we have is universal competition as a feature of universal scarcity, only with the enterprises that engage in competitive activity doing so under different institutional rules of property rights, creating settings of cooperation-cum-conflict that we denote as entangled political economy.

With respect to Panel B of Figure 3, some political entities may be characterized as Big Players (Koppl and Yeager 1996; Koppl 2002). We should note that a Big Player is not distinguished by size but by a mode of operation that differs from that of ordinary market participants. The presence or absence of residual claimancy is one such distinguishing difference. Transactions between people who are working with their own capital may play out differently than transactions where one participant is working with inalienable capital. Commercial firms have strong incentive to settle disputes because they are working with alienable capital. If one party to a dispute is a political entity, say an Attorney General, the dispute may play out differently. For one thing, the Attorney General cannot claim any residual for settling the dispute. Even more, continuation of the dispute might generate valued publicity for an attempt at higher office. In any case, 
the Attorney General would generally not operate according to the same language of economic calculation as ordinary market participants.

Credit markets provide particularly good material for the operation of entangled political economy in light of the presence of Big Players. A credit transaction is a form of rental contract where a lender hands over temporary possession of an asset to a borrower. Rental contracts create opportunities for asset conversion that are not present with sales contracts, and so different institutional arrangements have grown up around rental contracts. The conversion of dyadic transactions into triadic transactions through the entrance of Big Players would seem to provide particularly fruitful analytical opportunities, which could not be so readily addressed within a framework of separated political economy. Most of those opportunities relate to changes inside orthodox aggregates rather than to aggregates themselves, with resulting changes in aggregates reflecting systemic properties of an entangled political economy, as we shall now explore in some detail for two specific cases.

\section{Current episode: The TARP as illuminated by entangled political economy}

We draw upon two episodes of crisis to better illuminate the relevance of our theory of entangled political economy. Though we maintain that entanglement is a relevant organizing framework during all periods of politico-economic activity, we argue that moments of crisis are particularly useful in demonstrating this relevance because crisis accelerates interaction between the two orders as demand for political responses increases in the wake of undesirable macro-outcomes (see Higgs 1987).

Consequently, new relationships are formed across nodes as traditional boundaries are 
less respected. Finally, this entanglement occurs with greater transparency both because of the previous two arguments and because participants in the entanglement process are more likely to favor expediency over palatability.

To demonstrate how entanglement theory illuminates actions taken in a highly energized political economy, we must 1) explain how an entangled field for action is first formed by key political economy players, 2) identify the energized linkages that brighten during stressful times to deliver specialized benefits to emerging Big Players and related economic agents in the political economy, and then 3) show how an entanglement contagion develops that embraces other firms and industries in an inspired regulatory process. Along the way, we must describe the "gears in the transmission" that make the transfer mechanism work for key players. Our entanglement story offers a superior explanation to events relative to other theories of regulation such as public interest, capture, or special interest theory. ${ }^{4}$

In applying our theory, we first draw on the events that led to the creation of the Troubled Assets Relief Program (TARP). We must call attention to the 2007-2008 international financial collapse and world recession that preceded TARP. What followed in the United States was the most serious economic recession since World War II. We note that the credit collapse was associated with an unusual 2001-2005 expansion of credit for adjustable rate mortgage lending to less qualified borrowers and to investors (Taylor 2009: 1-10). As described by Yandle (2010a) and others, the credit collapse has no single cause that might be attributed to one overriding component or agent of the political economy but is rather the result of interacting necessary (but not sufficient)

\footnotetext{
${ }^{4} \mathrm{~A}$ summary and discussion of various regulation theories is found in Morriss, Yandle, and Dorchak (2009: 1-15).
} 
conditions instigated by rent-seeking interest groups that together had formed a economically vulnerable political/social structure which ultimately collapsed. Included in the structure were long-established linkages that delivered benefits from an entangled set of political agents, central bankers and regulatory agencies to mortgage bankers and lenders, credit rating agencies, accounting rule makers, insurance companies, and international broker/dealers. This was at a time when interest rates were low and the U.S. government was dedicated to expanding home ownership among lower income citizens (Sowell 2009: 30-50; Wallin 2008; Yandle 2010a). Enlarged use of the securitization and sale of mortgage-related debt instruments by major Wall Street bankers further accommodated the expanded lending. Mortgage-backed bonds found their way into the portfolios of financial and other institutions worldwide. The subsequent financial collapse became known as the sub-prime crisis, referring to a category of mortgages held as assets by major financial institutions. The magnitude and scope of ownership of these assets was so large and their value so questionable that banks, financial institutions and even governments worldwide found themselves teetering at the margin of bankruptcy. It was in the throes of this crisis that the connecting political economy linkages became highly energized and U.S. government officials supported a series of unprecedented actions. We draw on three episodes in the evolution of the TARP demonstrating the consequences of these newly energized entanglement network of relationships that connected political and market enterprises.

\section{1: Key events in the crisis and the thickening of entanglement}


Our first episode covers the emergence of the TARP in response to the financial crisis. We note that at the time when TARP emerged, the linkages between politicians, central banker, regulators, private bankers and insurance companies were well established and functioning. Robert Higgs (1987) explains how the arrival of a crisis provides opportunities for profit the exploitation of which thickens and energizes the extent of entanglement. The resulting stronger linkages and thickened entanglement are pertinacious and consequently remain in place after the crisis has passed (see Tullock 1975).

As described by the conventional wisdom of monetary economics, the traditional means of combating recessionary pressures and liquidity constraints is through the Federal Reserve. The Fed is endowed with a variety of tools to deal with perceived crises in the economy. Monetary policy actions taken by the Fed operate primarily through managing the money supply and influencing the federal funds rate, which is the interest rate charged in markets for overnight interbank borrowing. These powers granted to the Federal Deposit Insurance Corporation (FDIC) with regard to insolvent financial institutions theoretically enable bank regulators to stabilize the economy very much along the lines of a separated perspective.

During the initial stages of the reaction to the credit crisis, these organizations largely followed previously established guidelines for dealing with trouble in financial markets. For example, the federal funds rate set by the Federal Reserve averaged $1.81 \%$ in September 2008. This rate had fallen to $0.15 \%$ as of September 2009 . The Federal Reserve took these measures apparently in hope of expanding the credit market in light of the collapse of two government sponsored mortgage lenders, Freddie 
Mac and Fannie Mae, which molded the vast majority of the market for home loans made in the United States. Additionally, the FDIC later increased its deposit coverage insurance from $\$ 100,000$ to $\$ 250,000$ (see below). ${ }^{5}$

The reduction of the federal funds rate and primary credit responses by the FDIC to assist troubled financial institutions are traditional responses in times of crisis. The TARP, on the other hand, initially was justified as being critically necessary to remove bad debt from the banking system and "restart" the mortgage market. TARP would augment the use of the Federal Reserve's traditional tools in reducing the credit market crisis.

Working together in a rare burst of cooperation, U.S. Secretary of Treasury Henry Paulson and Federal Reserve Board Chairman Ben Bernanke searched the limits of their statutory powers and beyond for ways to inject credit directly into the balance sheets of the teetering banking community. There were a number of mechanisms considered, including providing cash by taking an equity ownership in the failing firms. However, a plan replaced this option that went directly to the problem, the deeply depressed mortgage-backed securities held by banks. Using the TARP, the Treasury would purchase these so-called toxic assets, hold them, and later sell them off, it was hoped, at a higher price than paid for them. In effect, the Fed was to become a hedge fund manager. But, of course, taking the action required congressional approval. The direct interaction of the Treasury, the Federal Reserve Board, and Congress that followed ended at least temporarily but perhaps permanently the much-celebrated independent position held by the U.S. central bank since the end of World War II.

In remarks before Congress, Secretary of the Treasury Henry Paulson claimed:

\footnotetext{
${ }^{5}$ http://www.fdic.gov/news/news/press/2008/pr08093.html
} 
We have proposed a program to remove troubled assets from the system. This troubled asset relief program has to be properly designed for immediate implementation and be sufficiently large to have maximum impact and restore market confidence. It must also protect the taxpayer to the maximum extent possible, and include provisions that ensure transparency and oversight while also ensuring the program can be implemented quickly and run effectively...

...Over these past days, it has become clear that there is bipartisan consensus for an urgent legislative solution. We need to build upon this spirit to enact this bill quickly and cleanly, and avoid slowing it down with other provisions that are unrelated or don't have broad support. This troubled asset purchase program on its own is the single most effective thing we can do to help homeowners, the American people and stimulate our economy. ${ }^{6}$

This initiative was first met with skepticism; on its first run through Congress, the statute failed to pass. A second attempt, however, which included certain unrelated provisions that may be thought of as side-payments, was successful and signed into law on October 3, 2008 as The Emergency Economic Stabilization Act of 2008. The Act was summarized as an effort "to provide authority for the Federal Government to purchase and insure certain types of troubled assets for the purposes of providing stability to and preventing disruption in the economy and financial system..."7 In effect, the Act gave Mr. Paulson an open hunting license to do almost anything to soften the crisis, and without required accountability to Congress or transparency of action so that taxpayers would be able to know who was being favored and who was not.

TARP represented a shift in the underlying constitutional order of how political enterprises relate to market enterprises with respect to financial intermediation, property rights, and the ability of boards of directors and corporate officers to manage their enterprises. This new enterprise was not grounded in the same bedrock as the political

\footnotetext{
${ }^{6}$ http://www.treas.gov/press/releases/hp1153.htm

${ }^{7}$ http://frwebgate.access.gpo.gov/cgi-

bin/getdoc.cgi?dbname=110_cong_public_laws\&docid=f:publ343.110.pdf
} 
enterprises it replaced. The defining of new entanglement territory was soon evident as the means to induce financial stability began to change rapidly in terms of the rhetoric and actions of the key political actors involved in its administration.

The ostensible purpose of the TARP, and the purpose in place when Congress approved the initiative, was to buy up so-called "toxic assets," those assets held by banks that were considered worthless due to their basis in the failing mortgage derivatives market. Yet as Congleton (2009) points out, this de jure purpose soon became inconsistent with the de facto actions taken by the Treasury Department. Instead of immediately purchasing toxic assets (i.e., mortgage-backed securities) as approved by Congress, the TARP's first action was to distribute $\$ 250$ billion in subsidies to nine large banks and financial institutions by purchasing preferred stock and warrants. ${ }^{8}$ The nine-bank "rescue," which was reluctantly embraced by some, unneeded by others, but unavoidably accepted by all formed a family of Big Players who would be armed to operate with relaxed bankruptcy constraints. Congressional review of the newly invented activity became the subject of yet another hearing where Congress called on Secretary Paulson to explain what was taking place. Without apologies, Mr. Paulson indicated that he was doing all in his power to avoid a world collapse of financial institutions, and that if necessary he might change his mind again. It is critical to our theory that congressional leadership accepted rather quietly Mr. Paulson's declaration of unlimited power to conduct the nation's business. Our entanglement theory predicts energizing and expanding the arteries that support the

\footnotetext{
${ }^{8}$ The represented banks were Bank of America Corp., Citigroup Inc., Goldman Sachs Group Inc., JPMorgan Chase \& Co., Merrill Lynch \& Co., Bank of New York Mellon Corp., State Street Corp., Morgan Stanley, and Wells Fargo \& Co.
} 
flow of politically produced transfers to economic agents already connected to the political engine.

\section{2: $\quad$ The gears in the TARP transmission}

It is now necessary for us to analyze this shift in more detail. What were the gears in the TARP transmission? How did Mr. Paulson and other key government players fertilize the field for entanglement growth? Recently released government documents show that Secretary of Treasury Paulson had a closed meeting with CEOs from the nine initial recipients of TARP monies, most of which were financially strong and needed no government assistance. ${ }^{9}$ In this meeting, Paulson all but ensured compliance with his plan of purchasing preferred stock by telling them that noncompliance "would leave you vulnerable and exposed" and further threatening regulation. $^{10}$

The Treasury soon extended this change in the allocation of the TARP funds beyond these initial nine firms. The Treasury described this new allocation method as follows:

Under the program, Treasury will purchase up to $\$ 250$ billion of senior preferred shares on standardized terms as described in the program's term sheet. The program will be available to qualifying U.S. controlled banks, savings

\footnotetext{
${ }^{9}$ The only rational explanation that we can offer for the strong-arming of sound financial institutions assumes that Secretary of Treasury Paulson and his advisors did not want to identify explicitly the weakest large bank in the financial system. Bank runs were already occurring. A bank panic could have been fomented when the invitation list became public.

${ }^{10}$ This comes from documents that reveal a list of talking points at the Oct. $13^{\text {th }}$ meeting. The points of relevance are:

- We don't believe it is tenable to opt out because doing so would leave you vulnerable and exposed.

- If a capital infusion is not appealing, you should be aware that your regulator will require it in any circumstance.

http://www.judicialwatch.org/files/documents/2009/Treasury-CEO-TalkingPoints.pdf
} 
associations, and certain bank and savings and loan holding companies engaged only in financial activities that elect to participate before 5:00 pm (EDT) on November 14, 2008. Treasury will determine eligibility and allocations for interested parties after consultation with the appropriate federal banking agency...

...Companies participating in the program must adopt the Treasury Department's standards for executive compensation and corporate governance, for the period during which Treasury holds equity issued under this program. These standards generally apply to the chief executive officer, chief financial officer, plus the next three most highly compensated executive officers. ${ }^{11}$

\section{3: $\quad$ How TARP expands entanglement beyond banking}

Our second episode concerns the shifting of the reported objectives of the TARP to incorporate other industries, especially the automobile industry. Here we describe how commercial organizations long accustomed to operating in a highly charged political economy adapted to the new political landscape by altering the nature of their transactions, appealing to newly endowed authorities using other politically expedient devices, or both. We trace the shift in the objectives of the TARP to accommodate these various industries starting with its purchase of additional senior stocks in American Insurance Group (AIG). AIG technically was the world's largest insurance company, had invested heavily in mortgage-backed securities and was also the leading writer of insurance, termed "credit default swaps," which protected sub-prime mortgage investors from default losses. AIG was technically bankrupt because of the operating losses related to the combination of investments and contracts.

\footnotetext{
${ }^{11} \mathrm{http}: / /$ www.ustreas.gov/press/releases/hp1207.htm. In addition to this noted activity, the Federal Reserve Board dramatically expanded the direct purchase of debt instruments including commercial paper from the commercial banking system. As a result, the Fed's balance sheet has shown unprecedented growth, raising serious concerns as to how the Fed will ultimately "unwind" its some \$1 trillion in newly acquired paper (Hamilton 2009: 67-84).
} 
With financial linkages that reached across the entire financial community, the government viewed AIG as too big to fail. This made AIG a Big Player, which is to say a firm without a bankruptcy constraint. As a result, the federal government had already become increasingly entangled with AIG, even before the establishment of the TARP. The Federal Reserve Bank of New York authorized a two-year loan of up to $\$ 85$ billion for AIG to draw upon following the collapse of Lehman Brothers and the dramatic fall in the value of AIG shares on September 16, 2008. ${ }^{12}$ They extended an additional loan of $\$ 37.5$ billion on October 8. ${ }^{13}$ On November 10, the Treasury Department assumed some of the financial burden by issuing a $\$ 40$ billion subsidy to purchase senior preferred stock. This allowed the Federal Reserve Bank of New York to reduce its previous allocation of $\$ 85$ billion to $\$ 60$ billion.

Given AIG's status as an insurance company rather than strictly a financial institution, it would seem that the TARP monies would not be applicable. However, in its press release the Treasury Department argued that it was necessary "to restructure federal assistance to the systemically important company." This shift of intended recipients of TARP monies from "qualifying U.S. controlled banks, savings associations, and certain bank and savings and loan holding companies engaged only in financial activities" to those deemed systemically important to the economy opened the door for Treasury to define the remaining distribution of TARP monies in any way that might satisfy crisis control logic.

In exchange for this subsidy, the Treasury stipulated the following:

Under the agreement, AIG must comply with the executive compensation and corporate governance requirements of Section 111 of the Emergency Economic

\footnotetext{
${ }^{12}$ http://www.federalreserve.gov/newsevents/press/other/20080916a.htm

${ }^{13} \mathrm{http}: / / \mathrm{www}$. federalreserve.gov/newsevents/press/other/20081008a.htm
} 
Stabilization Act. AIG must comply with the most stringent limitations on executive compensation for its top five senior executive officers as required under the Emergency Economic Stabilization Act. Treasury is also requiring golden parachute limitations and a freeze on the size of the annual bonus pool for the top 70 company executives. Additionally, AIG must continue to maintain and enforce newly adopted restrictions put in place by the new management on corporate expenses and lobbying as well as corporate governance requirements, including formation of a risk management committee under the board of directors. ${ }^{14}$

This new oversight of executive compensation practices was a characteristic of entanglement brought about by this allocation of TARP money.

Following this new disbursement practice, three of the largest national insurance companies, which were unaccustomed to federal regulation, took steps to qualify themselves as proper recipients of TARP money. These firms, Lincoln National, Hartford Financial Services Group, and Genworth Financial, each acquired federally regulated financial institutions to qualify for TARP. While Genworth was unable to secure TARP funding, on May 14, 2009, Lincoln Insurance Company and The Hartford both announced preliminary approval for the disbursal of TARP funds. ${ }^{15}$ These are just a few among many other companies such as CIT Group, Inc., GMAC, and IB Finance Holding Company, LLC that repositioned themselves in their various market characterizations to take advantage of the new political landscape. In most cases, there was a linkage to financial markets and investment in sub-prime mortgages, no matter how indirect. In some cases, though, the crisis to be met had more to do with countering rising unemployment and regional decline than sub-prime debt.

Perhaps the most apparent example of this came with the appeal of General Motors, Chrysler, and Ford to Congress for TARP funding. In testimony before

\footnotetext{
${ }^{14}$ http://www.ustreas.gov/press/releases/hp1261.htm

${ }^{15} \mathrm{http}: / / \mathrm{www}$.bloomberg.com/apps/news?pid=20601208\&sid=attbD0r7Nr70
} 
Congress, the CEOs of these firms argued that a combination of a weak economy, constrained credit institutions, and legacy costs associated with the provision of health care and retirement benefits to United Auto Worker union members was driving their companies into possible insolvency. GM and Chrysler asked for \$25 billion in TARP money. ${ }^{16}$ Ford Motor Company was not in such difficult straits; the company asked for a line of credit, not a direct injection of TARP money. Congress rebuffed this initial request, though, apparently failing to see how $\$ 25$ billion alone would save the automotive industry.

On December 19, 2008, President Bush, through an executive order, broadened the domain of TARP monies to include essentially any program deemed necessary to avert the financial crisis. The Bush administration utilized this stunning shift in the direction of the TARP to distribute funds to the ailing automotive industry by offering $\$ 9.4$ billion to General Motors and $\$ 4$ billion to Chrysler. These disbursements came amidst continued warning from both General Motors and Chrysler that all but declared pending bankruptcy and bought time for the two companies to operate until the new Obama Administration was in office. The Treasury offered even less in the way of justification for this new disbursement practice in the following press statement:

Treasury will make these loans using authority provided for the Troubled Asset Relief Program. While the purpose of this program and the enabling legislation is to stabilize our financial sector, the authority allows us to take this action. Absent Congressional action, no other authorities existed to stave off a disorderly bankruptcy of one or more auto companies. ${ }^{17}$

As the GM and Chrysler restructuring drew to an end, Senator Mike Johanns (R., Neb), without realizing it, described the key difference between an entangled crisis-

\footnotetext{
${ }_{16}^{16}$ http://www.nytimes.com/2008/11/19/business/19auto.html?_r=2\&em

${ }^{17} \mathrm{http}: / /$ www.treas.gov/press/releases/hp1332.htm
} 
driven process and the separated political process that would have taken place normally on the political commons: "I never would have believed as a candidate for the U.S. Senate that the U.S. government could buy GM without a hearing, with no vote, yes or no. There are billions and billions of dollars at stake here" (Mitchell 2009). Put differently, there was ignorance, rational or otherwise, regarding the total impact of the TARP-aided auto deal, but those with the most at stake were obviously well informed.

\section{4: $\quad$ Making the transition from crisis to leviathan}

The third period of our study describes how entanglement has spread into other features of the regulatory landscape. In particular, we point to such features as the oversight of executive compensation by a White house "Special Master for Compensation," a new and significant entanglement that has little to do with the original crisis (Solomon 2009a). Going beyond the TARP fund recipients, Treasury Secretary Geithner pushed for legislative authority to regulate executive pay for all financial institutions (Solomon 2009b). The emerging rules will move this feature of entangled regulation to a more stable position on the political commons. The growing regulation of financial institutions makes that sector look more like public utilities than market driven corporations subject to some regulatory constraints.

As executive pay and other constraints began to emerge, early recipients of TARP money, wary of continual government oversight, wished to pay back monies borrowed from the TARP fund to cut ties with federal overseers. ${ }^{18}$ According to the American Recovery and Reinvestment Act of 2009, which stipulates the procedure for repayment of TARP monies:

\footnotetext{
${ }^{18}$ See Smith (working paper) for an in-depth analysis of this withdrawal from TARP.
} 
Subject to consultation with the appropriate Federal banking agency (as that term is defined in section 3 of the Federal Deposit Insurance Act), if any, the Secretary shall permit a TARP recipient to repay any assistance previously provided under the TARP to such financial institution, without regard to whether the financial institution has replaced such funds from any other source or to any waiting period, and when such assistance is repaid, the Secretary shall liquidate warrants associated with such assistance at the current market price. (Division B, Title VII, Sec. 7001, SEC 111(g))

This provision indicates that the repayment of borrowed funds is not subject to scrutiny by the Treasury itself. What is de facto, however, is not de jure.

This became apparent as frustrated executives found a recalcitrant lender waiting. James Dimon, CEO of JP Morgan Chase claimed on April 17, 2009 in regard to repayment of borrowed TARP funds, "We could pay it back tomorrow. We have the money." ${ }^{19}$ Likewise Goldman Sachs Group Inc. has stated that its "duty" is to repay funds borrowed from the TARP. ${ }^{20}$

Yet the Treasury department did not allow immediate payment. Part of the reason here harkens back to the earlier controversy caused by AIG when it announced $\$ 165$ million in bonuses to top executives. This caused a "populist outrage" and spurred political representatives to take action against AIG. On March 19, 2009, the House passed a bill specifically tailored to the AIG incident, which levied a $90 \%$ tax on all bonuses received by employees making over $\$ 250,000$ annually and currently employed by companies receiving TARP monies. ${ }^{21}$ The Senate version reduced this tax to $70 \%$.

With the memory of the outrage against AIG fresh on the minds of lawmakers, the Treasury Department appointed an overseer to determine optimal compensation

\footnotetext{
${ }^{19}$ http://online.wsj.com/article/SB123986615199224399.html

${ }^{20} \mathrm{http}: / /$ online.wsj.com/article/BT-CO-20090414-708619.html

${ }^{21} \mathrm{http} / / / \mathrm{www}$.nytimes.com/2009/03/20/business/20bailout.html?pagewanted=1\&_r=1\&hp
} 
packages for seven of the largest firms receiving TARP funds. ${ }^{22}$ While Treasury has confined this overseer's area of responsibility thus far to these seven firms, the creation of the office alone points to the desire for increased political responsibility within previously market-only domains.

On September 24, 2009, approximately one year after the initiation of the TARP, Neil Barofsky, Special Inspector General for the TARP, testified before Congress regarding the progress of the initiative. As of September 11, 2009, the Treasury has allowed 41 banks to repay borrowed TARP funds. These firms were required to pass several "stress tests" to qualify for repayment including raising a substantial amount of private equity. Some of the firms are still negotiating the reacquisition of warrants extended to the Treasury. As of June 30, 2009, 649 U.S. banks had received $\$ 218$ billion in TARP money and $\$ 70$ billion has been repaid. Those still in the fold far exceed the number the Treasury has allowed to exit. ${ }^{23}$

Our discussion of TARP illustrates how existing linkages between public and private economic agents become energized, enlarged, and expanded when the economy is hit by a severe economic shock. Because it is not episodic but rather about process, entanglement theory better explains the tightened linkages between government and long-connected economic agents relative to competing theories of regulation. Our theory also accounts for new players in an expanded network of transfer and control. To demonstrate that our theory applies beyond the most recent crisis, we now illustrate how entanglement can be applied to a historic example of

\footnotetext{
${ }^{22}$ http://www.nytimes.com/2009/06/11/business/11pay.html?hp. These firms are American International ${ }_{23}$ roup, Citigroup, Bank of America, General Motors, GMAC, Chrysler, and Chrysler Financial.

http://sigtarp.gov/reports/testimony/2009/Testimony_Before_the_Senate_Banking_Committee_on_Bankin g_Housing_and_Urban_Affairs_\%209_24_09_Final.pdf
} 
energized government entanglement into the economy: the New Deal's National Recovery Administration.

\section{Historical episode: The NRA as illuminated by entangled political economy \\ Our historical episode of entanglement occurred during the Great Depression.} We draw parallels in entanglement between these separate episodes to demonstrate how unoriginal the TARP really is. Indeed our analysis calls into question the various normative policy suggestions typically offered in times of crisis, which invariably advocate yet more entanglement. Once again, we must 1) explain how an entangled field for action is first formed by key political economy players, 2) identify the energized linkages that brighten during stressful times to deliver specialized benefits to emerging Big Players and related economic agents in the political economy, and then 3) show how an entanglement contagion develops that embraces other firms and industries in an inspired regulatory process. We must also brush against the "gears in the transmission" that make the transfer mechanism work for key players.

The National Industrial Recovery Act (NIRA), signed into law by Franklin Delano Roosevelt on June 16,1933 , the last of the first 100 days, provides a prime example of entanglement. Of even greater interest to our story, the Supreme Court nullification of the NIRA just two years later on May 25, 1935 in Schechter Poultry v. United States (295 U.S. 495 (1935)) set in motion legislative action that replaced each critical part of the then defunct NIRA. Legislation passed in a matter of months included the Wagner Act, which replaced the NIRA's labor provisions, and the Robinson-Patman Act, which, 
as an anti-price cutting law, replaced the price codes. This legislative step illustrates the ever thickening entanglement among commercial and political enterprises.

The Great Depression was the crisis trigger. An international financial market meltdown followed by Federal Reserve and protectionist action yielded a deep economic collapse (Temin 1976). Out of the ashes came the New Deal and the 1933 legislation marathon that yielded the NIRA. There are obvious parallels between the TARP story and this one, with the National Industrial Recovery Act corresponding to the Emergency Economic Stabilization Act and the National Recovery Administration (see below) corresponding to the TARP itself. In both cases, a severe credit market shock, hurry-up legislation, and special deal making in the executive branch pushed the political economy into thickening entanglement. In this case, as with TARP, major industries, firms, and their agents had earlier formed close regulatory relationships with government. As documented by Higgs (1987), entanglement did not start with the New Deal, but rather with controls that emerged in World War I.

In placing his signature on the NIRA, President Roosevelt said (Deering, Homan, Lorwin, and Lyon 1934: 1):

History probably will record the National Industrial Recovery Act as the most important and far-reaching legislation ever enacted by the American Congress. It represents a supreme effort to stabilize for all time the many factors which make for the prosperity and the preservation of American standards. Its goal is the assurance of a reasonable profit to industry and living wages for labor, with the elimination of the piratical methods and practices which have not only harassed honest business but also contributed to the ills of labor.

The NIRA signing, moreover, was just one in a series of statutes signed in a matter of hours. These included the Glass-Steagall Act, which established new constraints on banking and initiated the FDIC, and legislation that reorganized the U.S. railroads (Alter 
2006: 304-305). Mr. Roosevelt reserved his most expansive comments for the NIRA statute, which he signed last in the series.

Described by Powell (2003: 113) as "FDR's biggest bet, his best hope, the flagship of the New Deal," the act gave Mr. Roosevelt almost unlimited power to intervene and manage the U.S. economy. With the signing of the NIRA, the president set in force activities that would eliminate child labor, set minimum wages for every U.S. industry, but not the same minimum wage, establish the maximum number of hours in the work week, require recognition of organized labor in the work place, and establish a gigantic bureaucracy for managing the federal cartel that was formed. In terms of our theory, Mr. Roosevelt and his operatives were "grazing" on a policy commons with most of the constitutional barbed wire cut and stored away, at least temporarily. The time was ripe to energize existing arteries that connected government and commercial agents and to enlarge the network by several orders of magnitude.

Just as now, there was a growing animus against capitalism and capitalists, especially those with high earnings and newly accumulated wealth. The NIRA drew on the model of Mussolini's fascism, which was popular at the time, and the idea that the corporate state could best manage a depression economy. Many leaders then believed that a new age of collective action and national planning had arrived, that free market capitalism was a dead letter. ${ }^{24}$

In a hearing on the act, Senator Robert F. Wagner, a leading proponent, emphasized that the time for planning and rationalization had arrived. He said

\footnotetext{
${ }^{24}$ Higgs (1987: 177) provides comments from the U.S. Chamber of Commerce and from Senator James F. Byrnes on the end of individualism. Byrnes said that businessmen were "clamoring for legislation providing government controls."
} 
Competition is not abolished; it is only made rational. In this bill we say that business may not compete by reducing wages below the American standard of living, by sweating labor, or by resorting to unfair practices. Competition is limited to legitimate and honorable bids in the market and real gains in technical efficiency (Dearing, Homan, Lorwin and Lyon 1934: 11).

The NIRA's preamble addressed the serious emergency faced by the nation, and in a first component empowered the president to develop industrial codes, industrial and labor coordination, gave the president power to regulate all prices and wages and addressed specifically the power of the president to regulate oil prices and pipeline operations (Dearing, Homan, Lorwin, and Lyon 1934: 116-124).

\section{1: $\quad$ The gears in the NRA transmission}

To provide gears in the transmission that would thicken and expand entanglement, the act established a massive bureaucracy charged with the responsibility of cartelizing every major sector and component of the U.S. economy, with each sector organized under a trade association, and with each industry association having a pricing code approved by FDR. A National Recovery Administration (NRA), established by the act and led by General Hugh F. Johnson, a retired Army general with considerable experience having been a part of the World War I bureaucracy. He was dedicated to the task, charged with managing and enforcing the emerging codes. By its very nature, the NRA would write and supervise hundreds of codes for as many industry sectors (Taylor 2007). Each sector and each firm in the sector would be highly informed about the fine print that governed their relevant sector. But it would be an impossible task for the leadership of any sector, firm or industry to keep up with the details of all other sectors. Consistent with the unavoidable division of 
knowledge, even those closely connected to NRA rules were largely ignorant outside their domains of particular expertise.

Full of enthusiasm for the task that lay before him, General Johnson used all the creativity he could muster to rally support for the Blue Eagle, the ubiquitous symbol he adopted for the NRA. He allowed businesses that toed the NRA line to fly the Blue Eagle flag and affix the Eagle imprimatur to their packages and include in their advertisements, and urged consumers to boycott non-Eagle producers (Higgs 1987: 179).

Once the NRA bureaucracy was up and running, there were 54 state and regional offices with 1,400 employees nationwide (Taylor 2002: 2). Approximately 700 industrial codes were put in place and these dealt with more than 150 trade practices, such as advertising, packaging, and product standardization. Along with codes came more than 11,000 administrative orders that affected some 2.3 million employers (Powell 2003: 121). In June 1935, the National Industrial Conference Board, the predecessor to today's Conference Board, reported that the NRA's two year operating cost had totaled $\$ 93.8$ million, which is equivalent to $\$ 1.4$ billion in 2009 dollars or approximately $\$ 700$ million per year (Cost of NRA rule put at $\$ 93,884,5951935$ ). To give some perspective to the magnitude of the operation, consider this: the 2010 budget for the U.S. Securities and Exchange Commission is $\$ 1.02$ billion (U.S. Securities and Exchange Commission Budget in Brief 2009) and the U.S. Federal Trade Commission's 2009 budget is $\$ 243$ million (U.S. Federal Trade Commission, 2009, Congressional Budget Justification 2009). Entanglement was being taken to the limit, or so it seemed. 
As might be expected, leaders of many major American corporations along with the U.S. Chamber of Commerce strongly supported the NRA. Indeed, when signed into law, the president of the U.S. Chamber referred to the act as the "Magna Charta of industry and labor" (Powell 2003: 114) ${ }^{25}$ Major players wanted to be regulated. Another major component of the act focused on labor and labor relations. The NRA effectively required industry to bargain collectively with organized labor and established a government mechanism for settling labor disputes. The NRA codes set minimum prices, minimum wages and maximum hours allowed in a workweek, based on a misguided theory that higher prices would translate into larger revenues for firms so that workers' take-home pay would increase.

That some industries were anxious to organize under the Blue Eagle cartel is revealed from the fact that the U.S. cotton textile industry had its NRA code written and approved by the president on July 9, 1933, less than one month after Mr. Roosevelt signed the authorizing legislation (Dearing, Homan, Lorwin and Lyon 1934: 141). The textile code illustrates the entangled fine-tuning accomplished within the context of the NRA, which also identifies one of the more interesting gears in the NRA transmission. Among other things, the textile code established minimum wages for just that industry with a small differential for northern and southern mills, $\$ 13$ for a 40 hour week in the North; \$12 in the South (Powell 2003: 121-122). The wages set were significantly higher than those prevailing at the time. Cotton textile manufacturing was rapidly moving South, and organized textile workers in the North used the Blue Eagle opportunity to raise wages and close the wage gap. New England textile mill operators

\footnotetext{
${ }^{25}$ The codes and trade association coordination components of the act, known as the Swope Plan, had been promoted for several years by Gerard Swope, president of General Electric (Powell 2003: 113). Herbert Hoover had rejected the Swope Plan in 1931, calling it and its supporters "sheer fascism."
} 
dominated the textile trade association. The first industry entangled with the Blue Eagle was the textile industry.

\section{2: Difficulties in building and keeping the cartel}

Just as with Treasury attempts to herd major U.S. banks into a TARP cartel, not every firm and industry was cooperative with the Blue Eagle. Henry Ford refused to sign the auto code drafted by General Motors and Chrysler. Powell (2003: 125-127) tells about Ford's opposition and how, because of this, the NRA threatened him with losing a bid to supply trucks to the government, just as Secretary Paulson threatened TARP-reluctant bankers with new regulatory initiatives. Ford was the low bidder and, ironically, paid the highest wages in the industry. While Ford won that bid, shortly thereafter Mr. Roosevelt issued an executive order that denied government business to any firm that did not fly the Blue Eagle. Mr. Ford's sales increased that year without government orders.

Mr. Ford was not the only one to express opposition to the Graphic Arts Code. As the NRA expanded its reach with codes and other rules, a growing number of 'misfits" began to emerge. Put another way, the cartel was costly to maintain. For example, in July 1934, in a first united protest against the NRA, a group of Bronx printers turned in their Blue Eagles in protest against the Graphic Arts Code that included them (70 Bronx printers return Blue Eagle 1934). The printers had petitioned relief from code-set wages. A representative for the group indicated that the Blue Eagle wages were about double those that prevailed before the code was adopted. 
Expressing support for the NRA concept and not wanting to appear radical, the statement went on:

It is unfair to expect medium or small-sized shops to pay the same scale of wages as the large plants when general conditions such as the amount and type of business and volume of production is taken into consideration. This schedule will place an unfair hardship on most of us and force many of us to go out of business (70 Bronx printers return Blue Eagle 1934).

Quite possibly, the larger firms in the industry knew exactly what they were doing when they contracted for a code that raised competitors' costs.

There were also occasions where special deals made by the NRA to some firms in an industry, but not to all, led to policy reversals (Cotton pay rise exemptions are granted; NRA aids 145 concerns, ten associations 1934). The growing power of the NRA to deal with specific firms as well as entire industries led the agency to use withdrawal of the Blue Eagle, a requirement for doing business with government, as the ultimate punishment for failure to abide by the codes. The sanction reached even to the level of the producers of dolls' clothes (NRA may restore a Blue Eagle here 1934). Eventually, while addressing such things as the prices of cigarettes, the NRA turned attention to Hollywood and began an investigation of movie stars' salaries (Movie salaries listed 1934), perhaps the counterpart to today's political concern with executive pay. The effort to maintain the Blue Eagle cartels became more troublesome as some firms tested the legality of the NIRA's antitrust exemption as well as its other powers. As might be expected, the agency opened a litigation department to handle the growing number of lawsuits. In November 1934, after having been in business just seven months, the litigation unit reported that 663 cases had been docketed and that the unit 
had prevailed in all but 10 of 129 court actions (NRA is winning $90 \%$ of its court tests 1934).

With a genius for recognizing opposition and neutralizing it, President Roosevelt named famous courtroom lawyer Clarence Darrow as head of a committee to review the NRA's operation. What may not have been expected was Darrow's fiery assessment that accused FDR of having attempted to monopolize markets and General Johnson of having made deals to alter codes after FDR had signed a "final" order (Johnson accused by Darrow board of altering code 1934). Custom-tailored entanglement was creating problems.

\section{3: The end of the Blue Eagle: from crisis to leviathan}

Amity Shlaes (2007) provides an interesting and colorful account of how Schechter Brothers Poultry Company, a Brooklyn-based chicken seller, became the plaintiff that ultimately brought down the NIRA and all its trappings. As she might have put it, the Schechter Chicken killed the Blue Eagle. A favorable Supreme Court decision came in a circuitous fashion. The Schechter firm was charged with violating the "Code of Fair Competition for the Live Poultry Industry in and around the Metropolitan Area in and about the City of New York," an NRA code title that illustrates the specificity of the rules. ${ }^{26}$ The firm was charged and convicted in the New York Federal Court (NRA is winning $90 \%$ of its court tests 1934). The brothers appealed the case to the U.S.

\footnotetext{
${ }^{26}$ To further illustrate the regulatory detail, under the rule in question "(1) It was required that an employee of the seller reach into a crate of chickens and grab out the birds one by one as they came to hand; (2) it was required that the buyer accept the chicken thus pulled forth" (End of NRA 1935: B1). This was the so-called "straight killing" rule, which prohibited selecting individual chickens from a crate. On June 20,1934, a Schechter employee allowed a customer to pick and chose several chickens from a crate, rejecting some perfectly healthy chickens in the process. It was outright chicken discrimination, illegal under the code.
} 
Supreme Court, which ruled unanimously in their favor by declaring that the NIRA unconstitutionally delegated powers to appointed officials to develop laws and regulations that carried criminal sanctions. The Court also ruled that interference in business transactions that did not involve interstate commerce represented an unlawful expansion of powers for the U.S. government.

The ruling was devastating to the FDR effort and to those industries that enjoyed NRA shelters from free market competition. If the NIRA was unconstitutional, other major statutes inevitably would follow. Mr. Roosevelt responded by charging that the decision took the country back to 1789 , in effect saying that the federal government was powerless to cope with the problems that came with the country's economic growth and development (End of NRA 1935). In terms of our model, the Court action brought to an end the chaotic activity on the commons. Without missing a beat, though, Congress and Mr. Roosevelt moved quickly to replace key gears in the NIRA transmission with newly enacted statutes.

The Schechter decision was rendered on May 27, 1935. On July 5, 1935, Mr. Roosevelt signed the National Labor Relations Act that effectively embodied the labor section of the NIRA. On June 5, 1935, lawmakers passed the Robinson-Patman Act, a statute that outlawed price-cutting. They passed the Connolly Hot Oil Act earlier, on February 22,1935 . That piece of temporary legislation was then extended to replace the NIRA's petroleum regulations. When considered in their entirety, the new legislation provided uniform wage and hour regulations, guaranteed the right of labor to organize with union representation of its choosing, eliminated child labor, cartelized oil production, and prohibited price-cutting. In terms of social structure, the NIRA had 
established trade associations as a prevalent American institution for lobbying and favor-seeking, and the NRA experience made Washington, D.C. the center of the nation's political economy. Thus, the links between political and commercial agents were strengthened; enlarged entanglement became a permanent feature of the modern U.S. economy.

\section{Some concluding remarks}

As our narrative illustrates, the entanglement of political and commercial enterprises typically thickens and expands in times of crisis, and with new degrees of entanglement becoming new norms going forward. What we witness in instances of crisis is the variable turbulence that is an operating characteristic of a system of entangled political economy. This perspective is hidden from the framework of separated political economy because that framework offers no theoretical space for emergent action within the aggregates we denote as polity and economy to transform a system of political economy. Entrepreneurs are always looking for profit opportunities; however, periods of crisis perhaps provide particular opportunities for seeking profits that generate systemic changes of an emergent nature that have enduring consequences, whether for good or bad.

For example, in times of stability, the Treasury likely would have used its resources as approved by a majority of the legislature in the fashion stipulated by the initial measure or would face the consequence of having these discretionary powers removed. Instead, the crisis enabled Mr. Paulson to maneuver far beyond his original mandate. Under the lens of entanglement, this dramatic shift in the direction of the 
TARP is understandable at least in form. Mr. Paulson's enhanced maneuverability demonstrates a certain understandable preference from the political side of the exchange. If Paulson had pursued the plan proposed to Congress, he would have implemented a reverse auction, which presumably would have resulted in so-called toxic assets going off the balance sheets of investment banks and on to the balance sheet of the Federal Reserve Board or the U.S. Treasury. Instead, by buying shares of certain financial institutions directly, the Treasury as a political enterprise became further entangled in the affairs of market enterprises by becoming essentially a shareholder rather than a bondholder. With ownership rights, Treasury as agent for taxpayers and Congress could extend its control by making demands on how TARPcontrolled firms would set loan policies and compensate executives. Furthermore, this enabled further discretion over repayment practices.

We make similar observations regarding Mr. Roosevelt and the NRA. Realizing that he was skating on thin constitutional ice, Mr. Roosevelt moved ahead anyway with one of, if not the most, significant restructurings of the U.S. economy to occur before or since. The Great Depression was the galvanizing event, but not the origin of expanded government and commercial entanglement. At the same time, Mr. Roosevelt and his political operatives were prepared for the day when the Court ruled his juggernaut unconstitutional. In a matter of months, key features of the NRA were embodied in congressional action. Key arteries that connect government with major sectors and industries were made a permanent part of the landscape.

This analysis is not meant to suggest that entanglement is initiated only by political entrepreneurs. For market actors are in many cases just as eager to increase 
their interactions with political enterprises. Such activity falls under the label of "rentseeking" and is an unalterable feature of the political marketplace. This observation calls into question at least one element of the argument that crises are purely a result of unrestrained political intervention. It must be recognized that political action can just as easily be initiated from market enterprises as their political counterparts.

Entanglement there surely always will be, much as Hughes (1977) recognized.

To some extent, however, the degree and the structure of entanglement can be subject to influence. If we start from an observation of such heart-wrenching financial problems as people losing their homes, it is natural to expect some collective version of the Samaritan's Dilemma (Buchanan 1975) to come into play. That dilemma can also operate for private persons, of course, and, indeed, this was Buchanan's original point. But it also intensifies in collective contexts, as Wagner (1989) explained in his extension of Buchanan's original insight, because individual responsibility weakens in collective settings, much as Caplan (2007) elaborates. Constitutional limits on the size of government or on the allowable range of its activities might mitigate some of the disruptive features of entanglement. We do not think that such entanglement can be eliminated, though, for we see such entanglement rather as an inescapable element of the human condition.

\section{Acknowledgements}

The authors express appreciation to two anonymous referees of this journal for helpful comments and criticisms. 


\section{References}

70 Bronx printers return Blue Eagle., 1934. New York Times (1957-Current File, ProQuest Historical Newspapers, The New York Times (1851-2005), (July 26): 21.

Alter, J. 2006. The Defining Moment. New York: Simon and Schuster.

Barabási, A-L. 2002. Linked: The New Science of Networks, Cambridge, MA: Perseus.

Besley, T. 2006. Principled Agents? The Political Economy of Good Government. Oxford: Oxford University Press.

Buchanan, J. M. 1975. The samaritan's dilemma. In Altruism, Morality, and Economic Theory, Edmund Phelps (ed.). New York: Russell Sage, pp. 71-85.

Caplan, B. 2007. The Myth of the Rational Voter. Princeton: Princeton University Press.

Cohan, W. D. 2009. House of Cards, New York: Doubleday Publishing Group.

Congleton, R.D. 2009. On the political economy of the financial crisis and bailout of 2008. Public Choice 140: 287-317.

Cost of NRA rule put at $\$ 93,884,596$. 1935. New York Times (1957-Current File, ProQuest Historical Newspapers, The New York Times (1851-2005), (June 10): 2.

Cotton pay rise exemptions are granted; NRA aids 145 concerns, ten associations. 1934. New York Times (1957-Current File, ProQuest Historical Newspapers, The New York Times (1851-2005), (December 10): 2

Dearing, C. L., Homan, P. T., Lorwin, L. L. and Lyon, L. S. 1934. The ABC of the NRA. Washington: The Brookings Institution.

End of NRA. 1935. New York Times (1957-Current File, ProQuest Historical Newspapers, The New York Times (1851-2005), (June 2): B1.

Eucken, W. 1952 [1990]. Grundsätze der Wirtschaftpolitik $6^{\text {th }}$ ed. Tübingen: J. C. B. Mohr.

Goldberg, J. 2008. Liberal Fascism. New York: Random House.

Hamilton, James D. 2009. Concern about the Fed's new balance sheet, in John D. Ciorciari and John B. Taylor, eds. The Road Ahead for the Fed. Stanford: Hoover Institution Press. 68-84. 
Hayek, F. A. 1945. The use of knowledge in society. American Economic Review 35: 519-30.

Higgs, R. 1987. Crisis and Leviathan. New York: Oxford University Press.

Hughes, J. R. T. 1977. The Governmental Habit: Economic Controls from Colonial Times to the Present. New York: Basic Books.

Ikeda, S. 1997. Dynamics of the Mixed Economy. London: Routledge.

Jacobs, J. 1992. Systems of Survival. New York: Random House.

Johnson accused by darrow board of altering codes. 1934. New York Times (1957Current File, ProQuest Historical Newspapers, The New York Times (1851-2005), (June 12): 1 .

Kessler, O. 2009. Towards an economic sociology of the subprime crisis. Economic Sociology: the European Electronic Newsletter 10: 11-16.

Koppl, R. 2002. Big Players and the Economic Theory of Expectations. New York: Palgrave Macmillan.

Koppl, R. and Yeager, L. B. 1996. Big players and herding in asset markets. Explorations in Economic History 33: 367-83.

Littlechild, S. C. 1978. The Fallacy of the Mixed Economy. London: Institute of Economic Affairs.

McChesney, F. 1997. Money for Nothing: Politicians, Rent Extraction, and Political Extortion. Cambridge: Harvard University Press.

Mitchell, J. 2009. Car chiefs grilled on dealer closings, The Wall Street Journal, (June 4): B1.

Morriss, Andrew P., Bruce Yandle, and Andrew Dorchak. 2009. Regulation by Litigation, New Haven: Yale University Press.

Movie salaries listed. 1934. New York Times (1957-Current File, ProQuest Historical Newspapers, The New York Times (1851-2005), (July 8): 8.

NRA is winning $90 \%$ of its court tests. 1934. New York Times (1957-Current File, ProQuest Historical Newspapers, The New York Times (1851-2005), (Nov. 5): 39.

NRA may restore Blue Eagle here. 1934. New York Times (1957-Current File, ProQuest Historical Newspapers, The New York Times (1851-2005), (June 30): 4. 
Ostrom, E. 1986. An agenda for the study of institutions. Public Choice 48: 3-25.

Ostrom, E. 2005. Understanding Institutional Diversity. Princeton, NJ: Princeton University Press.

Persson, T. and Tabellini, G. 2000. Political Economics: Explaining Economic Policy. Cambridge: MIT Press.

Posner, R. A. 2009. A Failure of Capitalism, Cambridge: Harvard University Press.

Potts, J. 2000. The New Evolutionary Microeconomics. Cheltenham, UK: Edward Elgar.

Powell, J. 2003. FDR's Folly, New York: Crown Forum.

Rowley, C. K. and Smith, N. 2009. Economic Contractions in the United States: A Failure of Government. London: Institute of Economic Affairs.

Shiller, R. J. 2008. The Subprime Solution, Princeton: Princeton University Press.

Shlaes, A. 2007. The Forgotten Man: A New History of the Great Depression, New York: HarperCollins.

Smith, A. Too big to use: conflict and the Troubled Assets Relief Program. George Mason University Working Paper.

Smith, A. and Yandle, B. 2009. Too big to fail, read, count, or stop, Regulation 32(2): 34.

Solomon, D. 2009a. White house set to appoint a pay czar, The Wall Street Journal, (June 5): A2.

Solomon, D. 2009b. Salaries safe, bonuses hit, The Wall Street Journal (June 10): A1, A4.

Sowell, T. 2009. The Housing Boom and Bust. New York: Basic Books.

Taylor, J. E. 2002. The output effects of government sponsored cartels during the New Deal. Journal of Industrial Economics L: 1-10.

Taylor, J. E. 2007. Cartel code attributes and cartel performance: an industry level analysis of the National Industrial Recovery Act. Journal of Law \& Economics 50: 597624.

Taylor, J. B. 2009. Getting off Track. Stanford: Stanford University Press. 
Temin, P. 1976. Did monetary forces cause the Great Depression. New York: W.W. Norton \& Company.

Tullock, G. 1967. The welfare costs of tariffs, monopolies, and theft. Economic Inquiry 5: 224-32.

Tullock, G. 1975. The transitional gains trap. The Bell Journal of Economics 6(2): 671678.

U.S. Federal Trade Commission, 2009, Congressional Budget Justification. 2009. http://www.ftc.gov/ftc/oed/fmo/budgetsummary09.pdf. Visited June 12, 2009.

U.S. Securities and Exchange Commission Budget in Brief, 2010. 2009. www.sec.gov/about/secfy10congbudgjust.pdf. Visited June 12, 2009.

Wagner, R. E. 1989. To Promote the General Welfare. San Francisco: Pacific Research Institute.

Wagner, R. E. 1999. Austrian cycle theory: saving the wheat while discarding the chaff." Review of Austrian Economics 12: 65-80.

Wagner, R. E. 2006. "Choice, catallaxy, and just taxation: contrasting architectonics for fiscal theorizing." Social Philosophy and Policy 23: 235-54.

Wagner, R. E. 2007. Fiscal Sociology and the Theory of Public Finance. Cheltenham, UK: Edward Elgar.

Wallin, P. 2008. Cause and effect: government policies and the financial crisis. Washington: American Enterprise Institute.

White, L. H. 2008. How did we get into this financial mess? Cato Briefing Paper No. 110. Washington: Cato Institute, November.

Woods, T. E. Jr. 2009. Meltdown, Washington, DC: Regnery, Inc.

Yandle, B. 1983. Bootleggers and baptists: the education of a regulatory economist. Regulation (May/June): 12-16.

Yandle, B. 1984. Intertwined Interests, Rentseeking, and Regulation, Social Science Quarterly 65: 1004-1012.

Yandle, B. 2010a. Lost trust: the real cause of the financial market meltdown, Independent Review. 14: 341-361.

Yandle, B. 2010b. We want to be regulated. The Freeman 60: 37. 


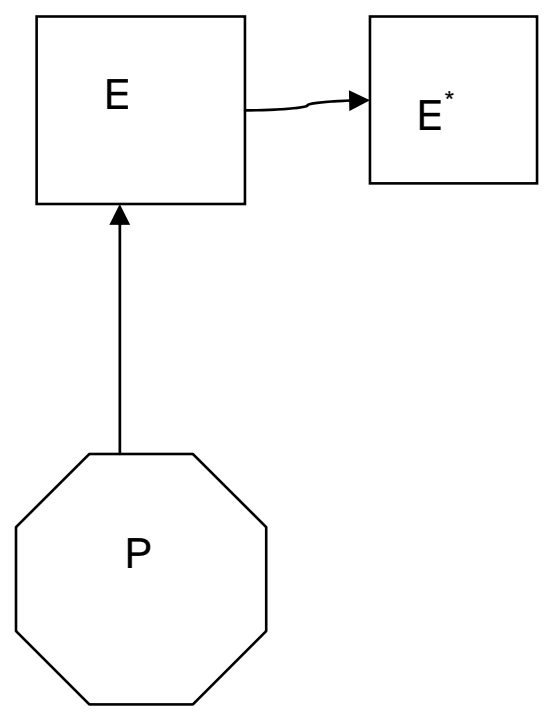

Figure 1: Separated political economy 


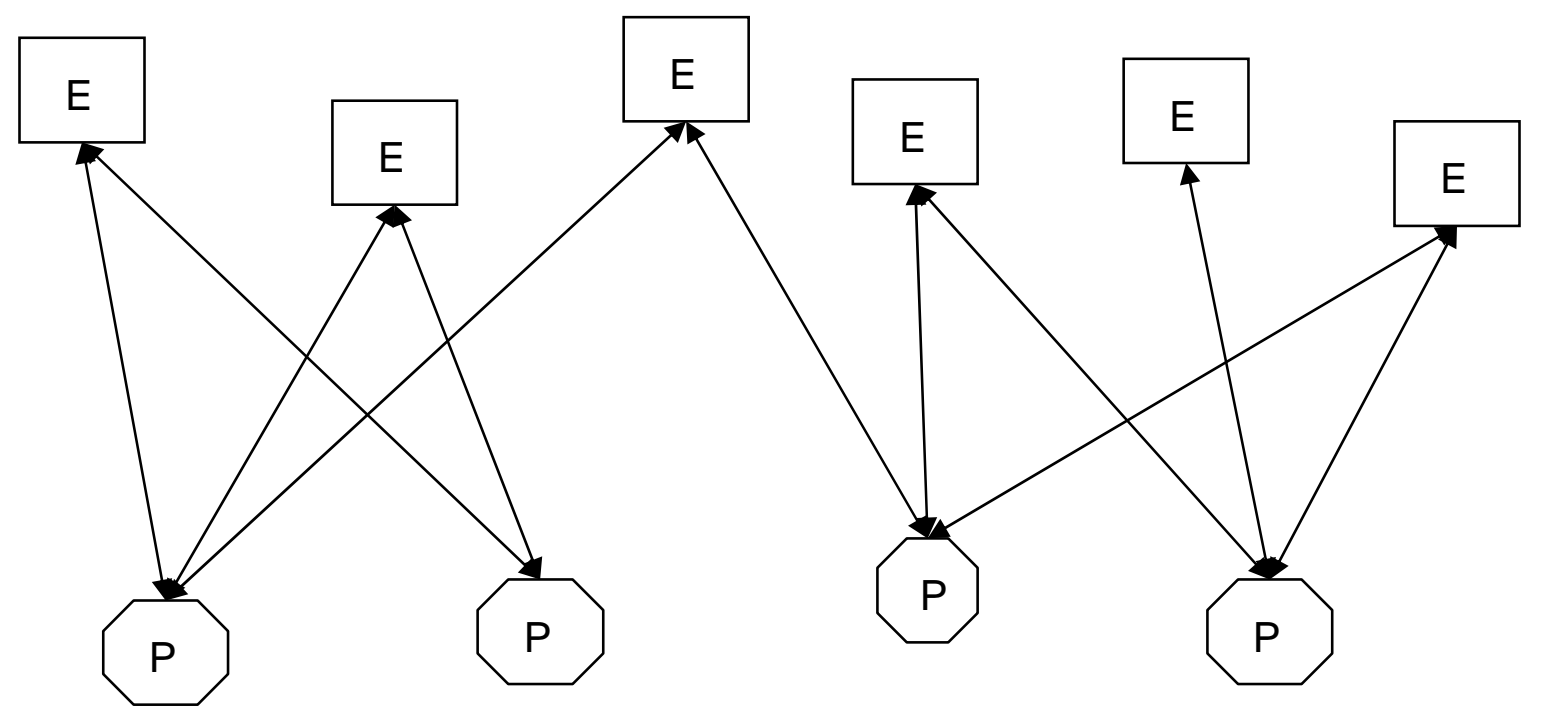

Figure 2: Entangled political economy 


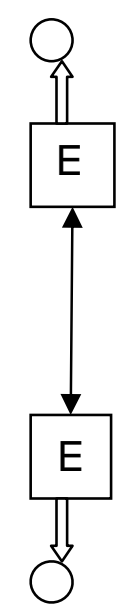

Panel A: Market exchange with separated political economy

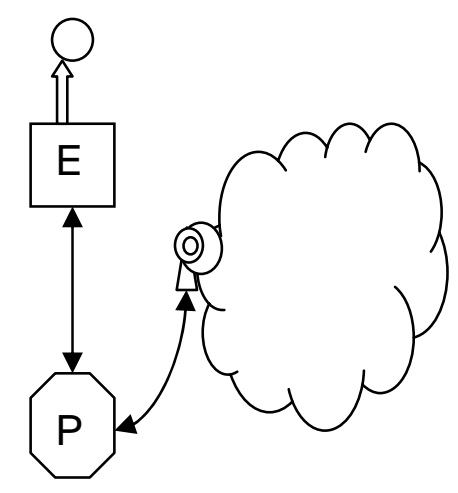

Panel B: Exchange within entangled political economy

Figure 3: Forms of exchange relationship in political economy 